\title{
The Life and After-Life of PH Pearse, Padraic Mac Piarais
}

\section{Clíona Ní Ríordáin}

\section{(2) OpenEdition}

1 Journals

\section{Electronic version}

URL: http://journals.openedition.org/etudesirlandaises/1904

DOI: 10.4000/etudesirlandaises.1904

ISSN: 2259-8863

\section{Publisher}

Presses universitaires de Caen

\section{Printed version}

Date of publication: 30 June 2010

Number of pages: 182-184

ISSN: 0183-973X

\section{Electronic reference}

Clíona Ní Ríordáin, «The Life and After-Life of PH Pearse, Padraic Mac Piarais », Études irlandaises [Online], 35-1 | 2010, Online since 30 September 2010, connection on 21 September 2020. URL : http:// journals.openedition.org/etudesirlandaises/1904; DOI : https://doi.org/10.4000/etudesirlandaises. 1904

This text was automatically generated on 21 September 2020 .

\section{(c) (i) (2)(2)}

Études irlandaises est mise à disposition selon les termes de la Licence Creative Commons Attribution - Pas d'Utilisation Commerciale - Partage dans les Mêmes Conditions 4.0 International. 


\title{
The Life and After-Life of PH Pearse, Padraic Mac Piarais
}

\author{
Clíona Ní Ríordáin
}

\section{REFERENCES}

Roisín Higgins \& Regina Uí Chollatáin (eds.), The Life and After-Life of PH Pearse, Padraic Mac Piarais: Saol agus Oidhreacht, Dublin, Irish Academic Press, 2009, 274 p., ISBN 978-0-7165-3012-1

1 Patrick Pearse, protean figure of Irish nationalism, here finds a volume worthy of his multiple incarnations. Róisín Higgins and Regina Ní Chollatáin have brought together a community of scholars who examine Pearse the educationalist, historian, republican, language advocate, writer and Dubliner. The volume, as indicated by its title, is bilingual, in as much as all Irish language contributions have been translated into English and both the preface and the introduction, and the headings are presented in Irish and English.

2 The volume is divided into three distinct sections: "The Dublin Man"; "History, Politics and Culture"; "Language, Literature and Education". The first section, which situates Pearse within his context both historical and geographical, contains four essays. Each of them is at pains to map out the society and the particular family context in which Pearse developed. Joop Augusteijn, in his article on the development of Pearse's political thought underlines the point that nothing in Pearse's background destined him to be a revolutionary. All the essays in this section engage with Ruth Dudley Edward's biography of Pearse, elaborating on certain biographical elements, as is the case with Brian Crowley's essay on the relationship between Pearse and his father; others like that by Joyce Padbury examine one particular aspect of his life, in this instance his friendship with Mary Hayden. Pat Cooke's illuminating "Patrick Pearse: The Victorian Gael", makes use of Samuel Beckett's term to examine how Pearse conformed to the Pan European mould of the era. Cooke examines the effects of 
Romanticism on Pearse and also makes the connection between Pearse and the flowering of children's fiction, speculating on the influences of Peter Pan on Pearse's play An Rí.

3 The five essays in the second section of the volume "History, Politics and Culture" are fascinating. Many of them challenge received wisdom regarding Pearse. Declan Kiberd's coupling of Pearse and Joyce will no doubt surprise many Joycean scholars but Kiberd argues convincingly that Pearse was a modernist, tracing his aesthetics, outlining the connections not just between Joyce and Pearse, Pearse and Wilde but also most daringly between Pearse and Beckett. For Kiberd, Pearse took "Irish aestheticism out of the monasteries and into the secular world of cultural politics". Kiberd draws on the multifaceted aspects of Pearse's life to illustrate his proposal, referring not just to his political actions but also to his literary work and to his educational involvement. Regina Uí Chollatáin focuses on Pearse's activity as a journalist, highlighting Pearse's role as a pioneering Irish language journalist. Other essays examine Pearse's relationship with and in history. Róisín Higgins studies the chronological evolution of the perception and reception of Pearse as a historical figure, outlining the ebb and flow of Ireland's relationship with an early icon of independence. She suggests that in the enduring visual image associated with Pearse (a head in profile) natural asymmetry is denied and he is frequently portrayed as a one-dimensional figure.

The final section of the book, "Language, Literature and Education", offers a useful recontextualisation of Pearse's literary and educational oeuvre. Angela Bourke argues that Pearse's short stories in Irish seek to create "an imagined community". She draws on written documentary evidence to underline the aspects of Conamara life that Pearse chooses to highlight. Pearse, like Yeats, created an ideal vision of the West. His stories rely on local folklore but Bourke stresses the fact that the religious life depicted in Pearse's stories was inspired by the new wave of Marian devotion and profoundly different from the "vernacular spirituality" of the Gaeltacht areas at the time. This discussion of Pearse's short stories is pursued in Róisín Ní Ghairbhís essay on "Pearse and Postcolonial Theory". As is the case with other critics, she stresses the international component in Pearse's Gaelic Revival, situating it both within the European and Colonial contexts. Eoghan Ó hAnluain examines the influence of Pearse on Máirtín Ó Direáin, while Caoimhín Breathnach studies Pearse's use of the Fiannaíocht cycle of stories. Brendan Walsh in his essay "Radicalising the Classroom: Pearse, Pedadogy of Progressivism" makes the connection between Pearse and Paulo Freire's Pedagogy of the Oppressed. Elaine Sisson, author of St Enda's and the Cult of Boyhood (2004), examines the construction of masculinity and citizenship in St Enda's.

5 Each chapter of the book is illustrated by photographs and stills from the Pearse Museum, UCD Centre for Irish Folklore, and the Irish Film Institute. This volume, with its index, notes and extensive bibliography, makes an important contribution to the repossession of Patrick Pearse, enabling the reader to see him as more than a one-sided nationalist icon. 